\title{
Patents and the Diffusion of Technical Information
}

\author{
By James Bessen*
}

March 2004

\begin{abstract}
Does the disclosure requirement of the patent system encourage the diffusion of inventions? This paper builds a simple model where firms choose between patents and trade secrecy to protect inventions. Diffusion is not necessarily more likely with a patent system nor is the "market for technology" necessarily greater.
\end{abstract}

Keywords: Patents, Innovation, Diffusion, Trade Secrecy

JEL Codes: K3, L5, O3

*Affiliations: Research on Innovation and Boston University School of Law (Visiting Researcher) Contact: jbessen@ researchoninnovation.org

Thanks to Ashish Arora, Robert Barr, Nancy Gallini, Wendy Gordon, Mark Lemley, Mike Meurer, Cecil Quillen and seminar attendees at MIT for helpful comments. 


\section{Introduction}

A common argument holds that the patent system promotes the diffusion of the technical information embodied in inventions: "Under our patent system, that which might forever remain locked up as a trade secret is now open for inspection (Rogan, 2002)." U.S. law requires each patent to disclose sufficient technical information to allow skilled practitioners of the art to recreate the invention, allowing the invention to diffuse. This benefit is separate from the argument that patents provide stronger incentives for innovation.

But survey evidence suggests that firms do not place much value on the disclosed information (Macdonald, 1998, Tang et al. 2001, Cohen et al. 2002). Moreover, those firms that do read patents do not use them primarily as a source of information on technology. Instead, they use them for other purposes, such as keeping track of competitors or checking for infringement (Oppenheim, 1998).

There are, in fact, sound theoretical reasons why the disclosed information may not be very valuable. Fritz Machlup and Edith Penrose (1950) report that the argument about diffusion is an old one, popular since the mid-nineteenth century. They also point out that, at least through the 1950s, economists have been skeptical about this argument.

The problem, also recognized in the mid-nineteenth century, is that "only unconcealable inventions are patented," so patents reveal little that could not be otherwise learned. On the other hand, "concealable inventions remain concealed" (Machlup and Penrose, 1950, p. 27). The disclosure argument appears to be based on a false, "apples to oranges" comparison-it assumes that under the patent system, all patentable inventions are patented. ${ }^{1}$ Since evidence shows that not all patentable inventions are patented (Cohen et al. 2000, Moser 2003), a more careful counterfactual comparison is required.

But this counter-argument does not take licensing into account. Although patentable inventions might diffuse both with and without a patent system, they might diffuse more rapidly under a patent system via licensing. Some advocates argue that the patent system facilitates "markets for technology," thus accelerating the diffusion of inventions to new

\footnotetext{
${ }^{1}$ For a more recent example of this counter-argument, see Friedman, Landes and Posner (1991).
} 
applications.

This note builds a simple model of disclosure with and without patents, with and without licensing. I evaluate specifically whether patent disclosure facilitates the diffusion of inventions within an industry given that diffusion may also occur via imitation or independent invention. Society benefits from diffusion because competition reduces deadweight losses. Also, diffusion may improve prospects for subsequent sequential innovations (Bessen and Maskin 2000, Green and Scotchmer 1990).

Denicolò and Franzoni (2004) have a complementary model with some stronger results, but they assume a specific demand function and imitation cost function.

The literature identifies other possible social benefits and costs of disclosure not directly considered here: disclosure may affect rent-seeking behavior (Boldrin and Levine 2004, Landes and Posner 2003); disclosure may communicate other uses for a technology (Landes and Posner 2003); disclosure may be used to signal costs of production or imitation (Horstmann et al. 1985, Anton and Yao 2004). Finally, disclosure improves the efficiency of the patent system by allowing potential innovators to know when they might infringe.

\section{Disclosure Model Without Licensing}

Consider a simple game involving two risk-neutral firms, A and B, in the same industry. ${ }^{2}$ Initially, assume that neither patents nor trade secrets can be licensed. There are two regimes: one with patent and trade secrecy law and another with only trade secrecy. Firm A has an invention that gives it a temporary monopoly. Firm B might like to share these profits. The interaction occurs in a simple game of sequential decisions with three stages (see Figure 1):

1) Firm A decides whether or not to patent, if patent protection is available.

Patenting costs $k$ more than trade secrecy alone. ${ }^{3}$

2) Firm B decides whether to develop a substitute invention independently or not. Firm B can develop such an invention by "inventing around" A's patents or

\footnotetext{
${ }^{2}$ The model can be extended to allow multiple firms to freely enter; results are similar.

${ }^{3}$ Landes and Posner (2003) point out that there are socially wasteful costs of maintaining trade secrecy. I assume that firms still maintain secrecy for non-disclosed knowledge even if they obtain patents. So $k$ is the incremental costs of patenting and I ignore explicit consideration of trade secrecy costs. Empirical evidence suggests that patenting costs (including enforcement costs) are substantially greater than the costs of trade secrecy (Lerner 1994).
} 
imitating ${ }^{4}$ firm A's product. To develop, firm B sinks a lump sum investment of $c^{i}>0, i=S, P$ where "S" designates that the invention is protected only by trade secrecy and "P" designates patent protection. Given this investment, firm B invents successfully with probability $q^{i}, i=S, P, 0 \leq q^{i} \leq 1$.

3) The firms produce.

The payoffs are determined as follows. Consider first a regime without patents. If firm B successfully invents a substitute, both firms earn a stream of duopoly profits. The present value of this stream is $V_{D}$. If firm B does not successfully invent, then firm A earns monopoly profits with present value $V_{M}$, and firm B earns 0 . Let $V_{M} \geq 2 V_{D}$.

If patents are available, but firm A chooses only trade secrecy protection, then the same payoffs will apply. I assume firm B cannot patent and exclude A. ${ }^{6}$

If firm A patents and firm B invents around the patent, both firms earn duopoly profits. Finally, if firm A patents and firm B does not invent around that patent, firm B nevertheless imitates costlessly once the patent expires. In a more elaborate model in continuous time, with discount rate $r$ and patent term $T$, firm A would earn $\left(1-e^{-r T}\right) V_{M}+e^{-r T} V_{D}$ and firm B would earn $e^{-r T} V_{D}$. For simplicity, the model developed here considers diffusion only at a single point in time $-q^{i}$ are probabilities rather than hazard rates. To capture the effect of diffusion at patent term, I define a probability of diffusion with unimitated patents of $\underline{q} \equiv e^{-r T}$. This clearly generates the same expected profits as in a more elaborate model in continuous time. For consistency, $q^{P}>\underline{q}$ where $q^{P}$ implicitly includes the diffusion at patent term.

The payoff matrix for the regime with patents is then

\footnotetext{
4 This includes reverse engineering, where firm B gains some useful information about A's technology for the product, and also independent invention.

${ }^{5}$ The results of this section only require $V_{D}<V_{M}$.

6 Under US patent code 102(b), if the invention was for use or sale for one year prior to B's invention, B is barred from obtaining a patent. This applies to cases where the invention is embodied in a commercial product, even though the invention may be hard to reverse-engineer (such as the inside of a safe, Hall v. MacNeale). Under US Code 102(g), firm B can obtain a patent on a secret innovation if firm A "abandoned, concealed, or suppressed" the invention (and it is not a business process). As long as Firm B imitates relatively quickly (e.g. less than four years after A), firm A will most likely not have "concealed or suppressed" in this model (Paulik v. Rizkalla). Europe has a general prior use defense for both product and process inventions.
} 


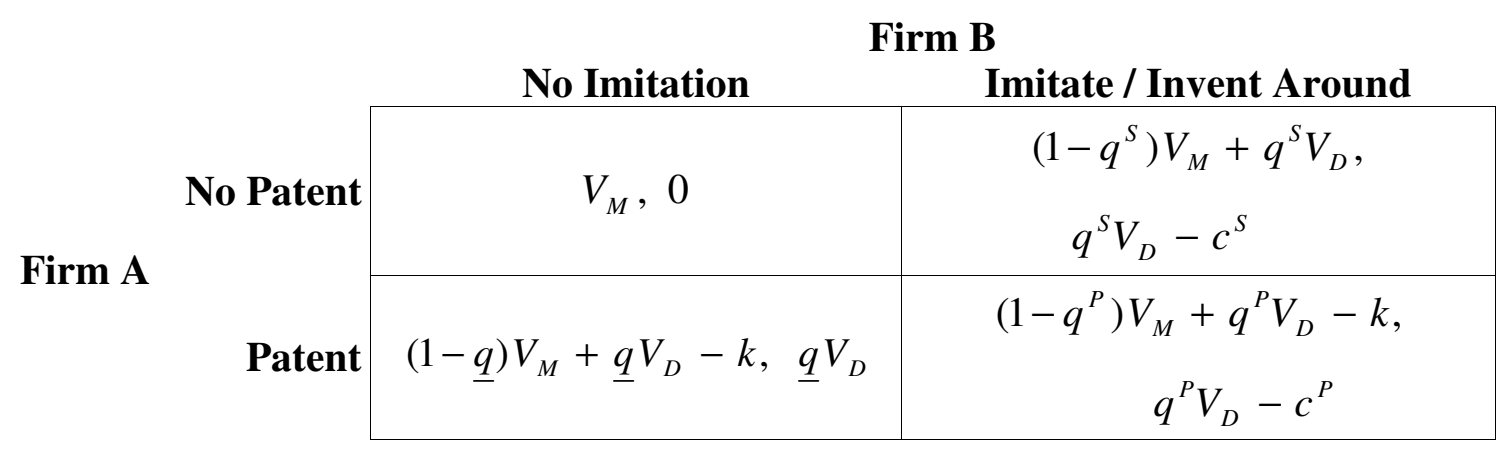

The payoff matrix for the no-patent regime is just the first row of this matrix.

To simplify the analysis, I temporarily assume that $c^{S}>\underline{q} V_{D}$. This is consistent with empirical evidence of substantial imitation costs (Mansfield et al. 1981).

The solution regions for the patent regime are shown in a phase diagram in Figure 2. The horizontal axis shows $q^{P}$, (beginning at $\underline{q}$ ) and the vertical axis shows $q^{S}$. Firm B will choose to invent around a patent when $q^{P}>\underline{q}+c^{P} / V_{D}$, corresponding to the right side of the figure. Firm B will choose to imitate a trade secret when $q^{S}>c^{S} / V_{D}$, corresponding to the upper half of the figure. Then, considering firm A's optimal choices, four distinct solution regions result as shown. Diffusion does not occur in region (D); in this case, "concealable inventions remain concealed." In region (A), diffusion only occurs when the patent expires. In regions (B) and (C), firm B actively attempts to imitate.

The patent regime can be compared to the no-patent regime by examining the differences in the probability of diffusion in each region of the phase diagram of the patent regime:

(A) In this case, the diffusion probability will be greater under the no-patent regime. In the patent regime, diffusion only occurs at patent expiration; without patents, the invention is actively imitated.

(B) In this region, active imitation occurs in both regimes, however, it is easy to show that for this region, $q^{S}>q^{P}$, so, again, diffusion is more likely in the no-patent regime.

(C) In this region, the firms behave the same in both regimes.

(D) In this region, behavior is also the same.

Comparing these results, it follows that Machlup and Penrose are basically correct: 
Proposition 1. For the case without licensing, the probability of diffusion under a patent system is less than or equal to the probability of diffusion under a regime with only trade secrecy, as long as $c^{S}>\underline{q} V_{D}$.

The intuition behind this result is simple: firms use patents when they reduce or eliminate imitation. Therefore, diffusion via imitation is less in these situations than if there were no patents. This result takes as given that the invention has been made, regardless of the legal regime. The discussion here concerns only diffusion and not invention incentives.

Note that faster diffusion does not necessarily imply greater social welfare if that diffusion is achieved with a greater expenditure of socially unnecessary cost. Imitation costs will be greater without patents in region A and possibly in region B, but the net social welfare effect depends on the benefits to diffusion, which could be large. Denicolò and Franzoni (2004) find that social welfare is greater with patents, but their result depends on a specific functional relationship between $c^{S}$ and $q^{S}$ and an optimal patent term, which may be quite short.

If the patent term is short, competition is soft and/or $c^{s}$ is small so that $c^{s}<\underline{q} V_{D}$, then a limited region exists where the invention will diffuse at patent term in a regime with patents, but would be kept concealed in a no-patent regime.

\section{Model with Licensing}

These results may change when licensing is considered. Indeed, it is often argued that patents facilitate the licensing of technology and promote "markets for technology." On the other hand, the empirical evidence indicates a robust (though perhaps imperfect) market for technology know-how that does not necessarily involve patents. This section extends the model above to consider licensing.

First, it is important to distinguish technology transfer agreements, which involve technical information and may or may not include patent rights, from pure patent licenses, which provide patent rights but do not provide the licensee any new technical information or "know-how." Pure patent licenses merely permit the licensee to operate without threat of litigation. Diffusion concerns true technology transfer licenses, so these are the only licenses I consider here. 
The literature identifies two relative virtues of the patent system for licensing: 1) it may be relatively difficult to contract over trade secrets, and, 2) the incentives to license patents may be greater. I consider each issue consecutively.

\subsection{Contracting over trade secrets and patents}

Cheung (1982, p. 44) argues that a defect of trade secrecy is "the obstruction of the spread of new ideas which could otherwise be put to use through contractual agreements." The literature identifies two main differences between patents and trade secrets that affect technology licensing: verifiability and expropriation. First, consider whether use of an invention can be verified by a third party. Cheung calls observability the "key element of patents:" well-defined specification and claims allow courts to make a determination whether a licensee (or possible infringer) is actually using a patented invention or not. This is important for contract enforcement against licensees who, once they have obtained knowledge of the invention, might claim to be using some other technology.

Clearly, many trade secrets lack such clear definition. However, the problem posed here specifically concerns patentable inventions, which could be protected either by trade secrecy or patent. The very same specification and claims contained in a patent could be written up for a trade secret, allowing a court to determine similarly whether the licensee is, in fact, using the invention or not. Detailed technical documentation serves this practical purpose in many technical know-how licenses. The enforcement of the contract only differs as to whether it is conducted under contract law or patent law. Moreover, enforcement of a technical know-how contract may have an advantage over a patent license: a patent license may lose force if the patent is declared invalid (perhaps as the result of actions by a third party). So, verifiability does not seem to raise a particular problem for licensing trade secrets in the situation considered here.

However, the second issue, the possibility of expropriation, does raise a particular concern, especially with trade secrets. The problem arises during the negotiation of a contract when the quality of the invention is private knowledge of the inventor. ${ }^{7}$ Suppose there are "good" inventions that generate profits and "bad" inventions that do not. The

\footnotetext{
${ }^{7}$ Alternatively, a problem arises if the licensee is not sure that the licensor is providing the "good" information it may have. This is equivalent to the case modeled here.
} 
prospective licensee will want some assurance that the invention to be licensed is of the good type. One way, but not the only way, the inventor can provide this assurance is to disclose sufficient information to the prospective licensee. But doing so risks expropriation-not yet subject to a contract, the prospective licensee may use the disclosed knowledge without licensing it.

Here patents have an advantage: in the event of expropriation, a licensor with a patent may sue for infringement, while a licensor with only trade secret protection may have little legal recourse. But this does not mean that technologies cannot be licensed without patent protection.

Indeed, the literature shows that private agents are often quite versatile at contracting around such obstacles. ${ }^{8}$ For instance, contracts may specify royalties contingent on some ex post observable performance such as sales and avoid ex ante disclosure altogether. This may be sufficient to separate "bad" inventors from "good"—-bad inventors, facing zero or negative profits, may not sign such a license. Alternatively, Arora (1995) shows that tacit knowledge of uncertain quality can be licensed when bundled with complementary goods or services.

Also, Anton and Yao $(1994,2002)$ show that a small inventor may safely disclose part or all of the invention prior to contracting as long as the prospective licensee has a competitor. The inventor can threaten to license the competitor. As long as duopoly profits are positive and the licensee makes greater profits with a monopoly on the invention, this threat is sufficient to deter expropriation.

Thus, except for the situation of a small inventor trying to license a monopolist, it appears that trade secrets can be licensed wherever patents can be licensed. In practice, there is a robust market in technology licenses that do not include patents. Indeed, Contractor (1981) found that only $39.5 \%$ of technology transfer agreements with unaffiliated licensees included the transfer of patent rights. More generally, survey evidence finds that patent licensing is a relatively unimportant channel for firms to obtain technical knowledge in comparison to consulting, research collaborations, etc. where private technical information (presumably trade secrets) is transferred as part of a bundle of services (Agrawal and Henderson 2002).

\footnotetext{
${ }^{8}$ Gallini and Wright 1990, Arora, 1995, Arora, Fosfuri, Gambardella, Anton and Yao, 1994,2002.
} 


\subsection{The "market for technology" under full information}

But do patents provide stronger incentives for licensing? It is sometimes argued that patents, especially "strong" patents, promote markets for technology. Patents are held to improve the inventor's bargaining position in any licensing negotiation. This generates larger royalty income, hence providing a stronger incentive to license. With strong patent rights, the argument goes, inventors will choose to license more often.

A simple extension of the model above demonstrates that this intuition is not correct. Consider this modified game: in stage 2a, firm A decides whether it wishes to engage in licensing. If so, then in stage $2 \mathrm{~b}$ the firms bargain. If not, then $\mathrm{B}$ can choose to imitate as above (it turns out that the firms will always agree on a license if firm B can feasibly imitate, so this does not occur). Then, in stage 3 , if the firms do not license, profits are as above; if the firms do license, the license determines their profits.

The firms will find it profitable to license when joint profits under a license exceed the joint profits achieved without cooperation, that is, when there is a net bargaining surplus. Suppose that firm A can craft an optimal license with firm B such that the joint profits are $V_{M}$ with trade secrets and $V_{M}-k$ with patents.

The joint profits without cooperation depend on whether firm B chooses to imitate or not. If B does imitate, non-cooperative joint profits are

$$
\left(1-q^{S}\right) V_{M}+2 q^{S} V_{D}-c^{S} \text { and } \quad\left(1-q^{P}\right) V_{M}+2 q^{P} V_{D}-k-c^{P}
$$

for trade secrets and for patents respectively. The net bargaining surpluses (the cooperative joint profits less the non-cooperative joint profits) are then

$$
c^{i}+q^{i}\left(V_{M}-2 V_{D}\right)>0, \quad i=S, P .
$$

In words, a cooperative agreement saves imitation costs and dissipation of rents to consumers. This means that licensing will occur in regions $\mathrm{B}$ and $\mathrm{C}$ in a patent regime and will occur in the entire upper portion of the phase diagram (A, B and C) in a regime with no patents. ${ }^{9}$

On the other hand, in region $\mathrm{D}$ (no patents, no imitation), the net bargaining surplus is zero and licensing does not occur. Further, I assume that antitrust considerations prevent a license that permits monopoly profits after a patent expires in region A. So

\footnotetext{
${ }^{9}$ Note that because the net bargaining surplus may be greater without patents, firm A's profits from licensing are not necessarily greater with patent protection.
} 
here, too, net bargaining surplus is zero and licensing does not occur in a patent regime.

Proposition 2. Assuming complete information, zero transaction costs, $c^{S}>\underline{q} V_{D}$, every technology licensed in a regime with patents will also be licensed in a regime without patents and some technologies licensed in a no-patent regime will not be licensed with patents.

In other words, the extent of the market for licenses may actually be greater without patents. The intuition is simple: licensing occurs where there is a credible threat of imitation. Because imitation occurs in more restricted circumstances with patents than without patents, the extent of licensing is less with patents. As above, technologies with very low imitation costs may have exceptions for certain parameter values.

This proposition assumes symmetric information and no transaction costs. These may also make results ambiguous. However, here, too, transaction costs for licensing trade secrets would have to be very large to offset the broader range of circumstances where firms would want to license without patent protection. The importance of nonpatent technology transfer employed by university professors suggests these costs are not large (Agrawal and Henderson 2002).

\section{Conclusion}

When firms can choose whether to protect inventions by patents or by trade secrecy, this model suggests that diffusion of the technical information embodied in inventions is not enhanced by the patent system and may well be delayed. 


\section{References}

Agarwal, Ajay and Rebecca Henderson. 2002. "Putting Patents in Context: Exploring Knowledge Transfer from MIT," Management Science, v. 48, n. 1, pp. 44-60.

Anton, James J. and Dennis A. Yao. 1994. "Expropriation and Inventions: Appropriable Rents in the Absence of Property Rights," American Economic Review, v. 84, no. 1, pp. 190-209.

Anton, James J. and Dennis A. Yao. 2002. "The Sale of Ideas: Strategic Disclosure, Property Rights, and Contracting," Review of Economic Studies, v. 69, no. 3, pp. 513-31.

Anton, James J. and Dennis A. Yao. 2004 (forthcoming). "Little Patents and Big Secrets: Managing Intellectual Property," RAND Journal of Economics.

Arora, Ashish. 1995. "Licensing Tacit Knowledge: Intellectual Property Rights and the Market for Know-How," Economics of Innovation and New Technology, v. 4, pp. 41-59.

Arora, Ashish, Andrea Fosfuri, and Alfonso Gambardella. 2001. Markets for Technology: The Economics of Innovation and Corporate Strategy, Cambridge: MIT Press.

Bessen, James and Eric Maskin. 2000. "Sequential Innovation, Patents and Imitation," MIT Working Paper 00-01.

Boldrin, Michele and David K. Levine. 2004 "Rent-Seeking and Innovation," Journal of Monetary Economics, v 51, pp. 127-60.

Cheung, Steven N. S. 1982. "Property Rights in Trade Secrets," Economic Inquiry, v. 20, no. 1 , pp. 40-53.

Cohen, Wesley M., Richard R. Nelson, and John P. Walsh. 2000. "Protecting Their Intellectual Assets: Appropriability Conditions and why U.S. Manufacturing Firms Patent (or not)," National Bureau of Economic Research Working Paper 7552.

Cohen, Wesley M., Akira Goto, Akiya Nagata, Richard R. Nelson and John P. Walsh. 2002. "R\&D Spillovers, Patents and the Incentives to Innovate in Japan and the United States," Research Policy, v. 31, no. 8-9, pp. 1349-67.

Contractor, Farok J. 1981. International Technology Licensing: Compensation, Costs, and Negotiation. Lexington, Mass.: Lexington Books.

Denicolò, Vincenzo and Luigi Alberto Franzoni. 2004. "The Contract Theory of Patents," International Review of Law and Economics, v. 34, pp. 365-80.

Friedman, David D., William M. Landes, and Richard Posner. 1991. "Some Economics of Trade Secret Law,” Journal of Economic Perspectives, v. 5, no. 1, pp. 61-72. 
Gallini, Nancy and Brian Wright. 1990. "Technology Transfer under Asymmetric Information," RAND Journal of Economics, v. 21:1, pp. 147-160.

Green, Jerry and Suzanne Scotchmer. 1990. "Novelty and Disclosure in Patent Law," RAND Journal of Economics, v. 21 n. 1, pp. 131-46.

Horstmann, Ignatius, Glenn M. MacDonald, and Alan Slivinski, 1985, "Patents as Information Transfer Mechanisms: To Patent or (Maybe) Not to Patent," Journal of Political Economy. v. 93, pp. 837-58.

Landes, William M. and Richard A. Posner. 2003. The Economic Structure of Intellectual Property Law, Cambridge, MA: Harvard University Press.

Lerner, Josh. 1994. "The Choice of Intellectual Property Protection: Evidence from Civil Litigation," mimeo.

Macdonald, Stuart (1998), What the patent system offers the small firm, Summary Report, prepared for the ESRC.

Machlup, Fritz and Edith Penrose. "The Patent Controversy in the Nineteenth Century," The Journal of Economic History, v. 10, no. 1, pp. 1-29.

Mansfield, Edwin, Mark Schwartz and Samuel Wagner. 1981. "Imitation Costs and Patents: An Empirical Study,” The Economic Journal, v. 91, pp. 907-18.

Moser, Petra. 2002. "How do Patent Laws Influence Innovation? Evidence from Nineteenth Century World Fairs." .

Oppenheim, Charles (1998), How SMEs use the patent literature, Summary Report for the UK Economic and Social Research Council.

Rogan, James E., Director, US Patent and Trademark Office, Speech at National Academies of Science, February 6, 2002.

Tang, Puay, John Adams and Daniel Pare, (2001), "Patent protection of computer Programmes" Submitted to European Commission, Directorate-General Enterprise. 
Figure 1.

Firm A:

Diffusion

Probability

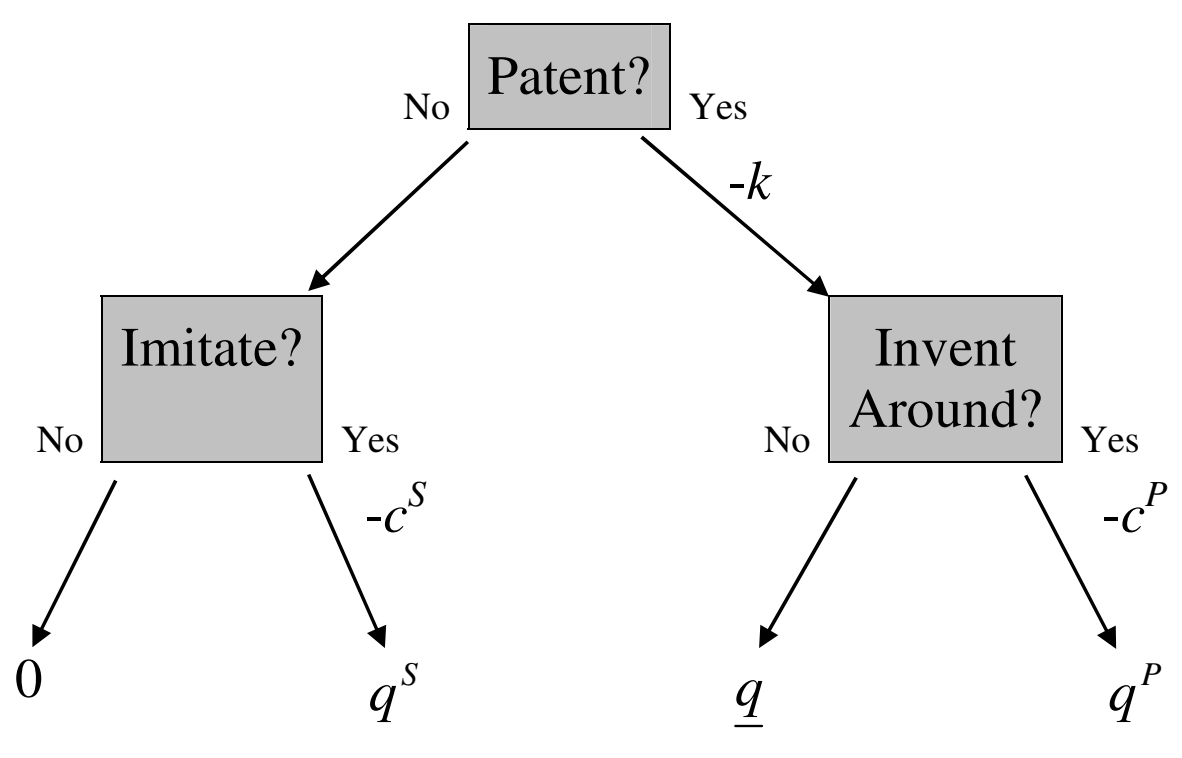

Figure 2.

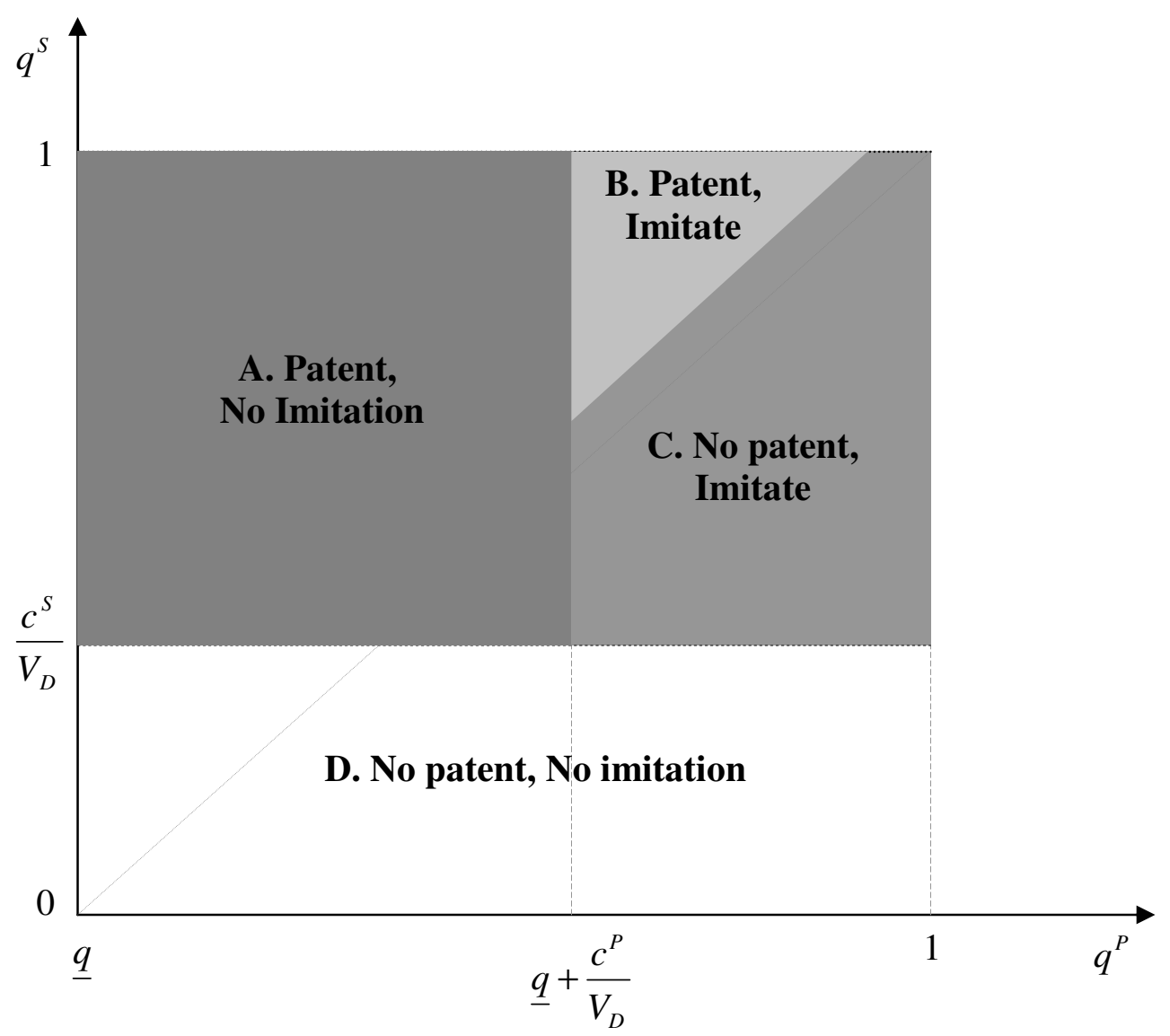


